\title{
Diversity of leptocephalus larvae around the island of Barbados (West Indies): relevance to regional distributions
}

\author{
D. E. Richardson*, R. K. Cowen \\ Marine Biology and Fisheries Division, Rosenstiel School of Marine and Atmospheric Science, University of Miami, \\ 4600 Rickenbacker Causeway, Miami, Florida 33149-1098, USA
}

\begin{abstract}
The cryptic nature of many elopomorph species and their occupation of minimally explored habitats have led to the underestimation of their importance as a component of regional biodiversity. Additionally, it had led to their exclusion from studies that seek to resolve the processes and life history traits important in determining the geographic distributions of species. Collections of the larval stage of elopomorphs provide one means of addressing regional diversity in this taxa. Plankton tows around Barbados during 4 separate years collected 68 identifiable taxa of the leptocephalus larval form unique to elopomorphs. While most of these species have either been collected as adults in the Lesser Antilles or upcurrent in the Guyanas, there remained 11 species whose adults are not known from either biogeographic area, and 7 leptocephalus types of species not described as adults. To determine whether these leptocephali were likely to be the product of local spawning, or alternatively expatriates from the Guyanas, temporal patterns of length frequency distributions and abundance of each species were analyzed with respect to regional oceanographic conditions. High abundances and small leptocephali of species probably expatriated from the Guyanas were found to coincide with periods when North Brazil Current (NBC) rings were present around Barbados and locally produced coral reef fish larvae were flushed away from the sample area. Minimum size classes and high abundances of Lesser Antillean species were more sporadic over time. While this work does help establish the geographic distribution of a number of rare and less frequently encountered species, it also highlights the lack of knowledge about elopomorph distributions that justifies their exclusion from biogeographic studies reliant on accurate fine-scale distribution patterns. However, a comparison of species distributions across major biogeographic boundaries indicates that elopomorph species as a whole are more broadly distributed than perciform species, a pattern attributable to many unique characteristics of their leptocephalus larval stage.
\end{abstract}

KEY WORDS: Leptocephali · Elopomorpha $\cdot$ Larval transport $\cdot$ Eels $\cdot$ Lesser Antilles $\cdot$ Guyanas $\cdot$ North Brazil Current ring

Resale or republication not permitted without written consent of the publisher

\section{INTRODUCTION}

In the western North Atlantic, about 200 elopomorph species in 4 different orders-Anguilliformes (true eels), Elopiformes (ladyfishes and tarpon), Albuliformes (bonefishes and spiny eels) and Saccopharyngiformes (gulper eels) - are known to inhabit bathypelagic, mesopelagic, deep benthic, continental slope and continental shelf environments (Böhlke 1989a). Aside from the few species targeted by fisheries, a majority of species in the subdivision Elopomorpha are rarely observed or collected because of their cryptic nature or their occupation of less frequently explored habitats (Smith 2002). This has resulted in limited knowledge about the abundance and spawning habits of most of these species and the geographic distribution of a number of them, and has probably prevented the discovery of other species. Analyses of the distribution of the leptocephalus larvae, unique to this subdivision, offers one means of addressing these issues. 
In the western North Atlantic, leptocephali are well described at the species level, and are readily identified by a combination of meristics and pigment patterns (Böhlke 1989b). However, despite the availability and ease of species level identification, most ichthyoplankton studies resort to grouping all leptocephali together, or to using only a few questionable family groupings. In the western North Atlantic, the exceptions to this have primarily been in the subtropical areas, including the Gulf of Mexico (Smith 1989c, Crabtree et al. 1992), Straits of Florida (Limouzy-Paris et al. 1994, Miller 1995), Sargasso Sea (Miller \& McCleave 1994), and Bermuda Ocean Acre (Keller 1976), leaving the tropical areas with a relative scarcity of species level accounts of the leptocephali fauna.

While leptocephali collections can contribute greatly to an understanding of regional elopomorph diversity, the presence of leptocephali in an area does not necessarily indicate the presence of adult populations in the same area. Regionally and temporally variable advective forces may disperse larvae over large areas resulting in their presence in locations far from spawning sites and far from areas where they can successfully complete their life cycle. For this reason, exploratory surveys targeting the smallest leptocephali of a species (i.e. those that would have undergone minimal transport) have historically been used to determine the spawning grounds of elopomorph species (Schmidt 1922). Unfortunately, given the number of elopomorph species, the rarity of the leptocephali of some species and the problem of specieslevel identification of very small leptocephali, it is not practical to employ this technique for all species. Alternatively, comparisons of the abundance and size distribution of larval fishes between different water masses can allow conclusions about the spawning location of species without necessitating the collection of recently spawned individuals of every species (e.g. Hare \& Cowen 1991). For leptocephali this technique has most often been used to separate those species or populations that spawn offshore over deep water from those that are spawned along the continental shelf (Miller \& McCleave 1994, Miller 2002, Miller et al. 2002), although the technique could equally well be used to determine the geographic distributions of many species that tend to be rare in adult collections.

One consequence of the uncertainty in the geographic distribution of elopomorph species is their exclusion from studies that synthesize large-scale patterns of diversity and abundance and attempt to determine the processes and life history traits that structure these patterns. Most of these analyses have concluded that geographic range sizes are minimally related to pelagic larval duration (Victor 1986, Wellington \& Victor 1989, Thresher et al. 1989, Victor 1991, Victor \& Wellington 2000, Jones et al. 2002), although there is some indication that pelagic larval durations must be above a certain threshold for a species to be distributed across major biogeographic boundaries (Brothers \& Thresher 1985). These conclusions are based on a limited number of perciform taxa that differ in many relevant ways from the majority of elopomorph taxa. Although few well-validated aging studies have been done, the larval durations of a majority of elopomorphs are thought to exceed those of most perciform taxa. Additionally, unlike other fish larvae, leptocephali accumulate considerable energy stores during growth (Pfeiler 1986, Bishop et al. 2000) and may rely on the uptake of dissolved organic matter (Pfeiler 1986), the consumption of larvacean housings (Mochioka \& Iwamizu 1996), or both (Bishop \& Torres 2001) to meet their energetic requirements. These unique growth and feeding characteristics of leptocephali could result in very different temporal and spatial patterns of mortality relative to other fish larvae, differences that may be particularly magnified in the less productive areas of the open ocean that often lie between major biogeographic regions. The extensive migration undertaken by anguillid larvae demonstrates that the leptocephali of some species can successfully and consistently be transported across long distances and a range of oceanic environments. Determining whether the possession of a leptocephalus larval stage results in different biogeographic patterns for elopomorphs relative to more commonly studied taxonomic groups requires an inclusion of elopomorph taxa in comparative studies. This in turn requires a fuller recognition of the diversity of elopomorph species, the geographic distributions of these species and the ecology of their leptocephalus larvae.

The current study is based upon leptocephali collected around the island of Barbados, West Indies, during cruises in 1990, 1991, 1996 and 1997. As the easternmost island in the Caribbean, Barbados is positioned near the border of 2 biogeographic regions: the Lesser Antilles region with extensive reef development, and the Guyanan region characterized by significant river input, sedimentation and the lack of hard substrates. Previous analyses of the oceanographic and biological data from these cruises revealed the variable dynamics of flow around the island (Bowman et al. 1994, Cowen \& Castro 1994, Stansfield et al. 1995, Paris et al. 2002), the response of this flow to external forcing events associated with North Brazil Current (NBC) rings (Kelly et al. 2000, Cowen et al. 2003), and the impact of these physical processes on the transport of locally produced coral-reef fish larvae (Cowen \& Castro 1994, Paris \& Cowen 2004). The objectives of this study were to (1) describe the species composition of leptocephali in the late spring and early summer around the island of Barbados, (2) to determine likely 
source locations of leptocephali of species not recorded as adults from either the Lesser Antilles or the Guyanas, and (3) to compare large-scale distribution patterns of elopomorphs to those of other more commonly studied taxonomic groups.

\section{MATERIALS AND METHODS}

Site description. Barbados is a small $\left(430 \mathrm{~km}^{2}\right)$ corallimestone island located at $13^{\circ} 10^{\prime} \mathrm{N}$ and $59^{\circ} 30^{\prime} \mathrm{W}$. Along the west coast of the island, a fringing nearshore reef paralleled by an offshore bank reef are separated by a band of sand and coral rubble (Macintyre 1968). Habitats along the eastern end of the island are poorly characterized due to the rough sea conditions generally present in that area. The Barbados ridge runs from 75 kilometers to the north of the island at a depth of around $250 \mathrm{~m}$ to $25 \mathrm{~km}$ to the south of the island at a depth of $75 \mathrm{~m}$. From the ridge, and along both the west and east coast of the island, water depths rapidly drop off to over $1000 \mathrm{~m}$.

Biogeographically, Barbados is generally grouped with the Lesser Antilles, an area considered to extend from the Virgin Islands in the north to Tobago in the south and Barbados in the east (Fig. 1). The islands in

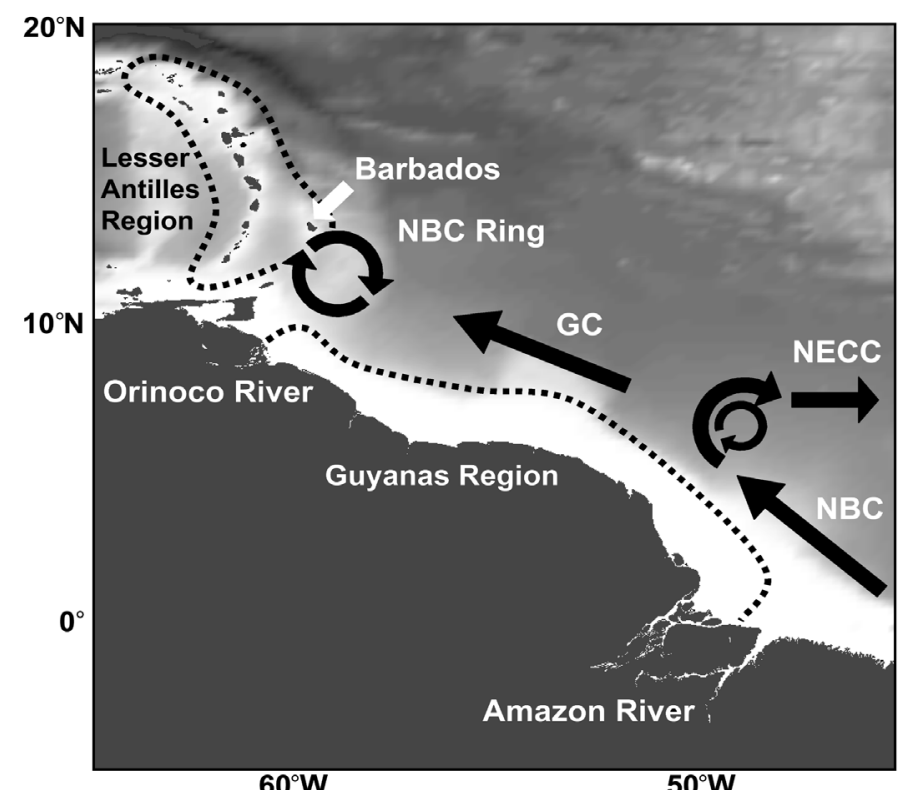

Fig. 1. Biogeographic regions and primary flow regimes in the vicinity of Barbados. Dotted lines: boundaries of Guyanas and Lesser Antilles biogeographic regions. The Guyana Current (GC) is consistently present along northeastern coast of South America; North Brazil Current (NBC) rings are more periodic, with about 6 forming per year at the retroflection of North Equator Countercurrent (NECC) and NBC. These translate northwest along the coast, before losing their form due to interactions with bathymetric features of Lesser Antilles this biogeographic region tend to be small, and the waters around them tend to be minimally influenced by runoff from land. Approximately 500 to $1000 \mathrm{~km}$ southeast of Barbados is the Guyanas biogeographic region, which is bounded by the Orinoco River to the north and west and the Amazon River to the south and east (Fig. 1). This region contrasts with the Lesser Antilles in the existence of extensive mangrove shorelines, the absence of carbonate geology and the presence of a wide continental shelf consisting primarily of soft-mud bottoms. The marine faunas of these 2 regions differ considerably, reflecting the habitat differences between them (Briggs 1974).

Regional oceanography. There are 2 main flow regimes in the region around Barbados. The first is associated with the Guyana current, which moves in a northwesterly direction parallel to the northeastern coast of South America. During certain periods this flow is interrupted by large anticyclonic rings formed at the retroflection of the NBC and North Equatorial Countercurrent (Fig. 1). About 6 of these NBC rings form per year, $6^{\circ}$ to $8^{\circ}$ north of the equator, where they entrain low-salinity water from the Amazon before moving northwest along the coast during the course of 3 to 4 mo (Fratantoni \& Glickson 2002). NBC rings move at an average speed of $14.5 \mathrm{~cm} \mathrm{~s}^{-1}$, though this speed can range from 7 to $30 \mathrm{~cm} \mathrm{~s}^{-1}$, while current velocities around the edge of the ring approach $100 \mathrm{~cm}$ $\mathrm{s}^{-1}$ (Fratantoni \& Glickson 2002). Circulation associated with the rings penetrates to depths below $200 \mathrm{~m}$ (Wilson et al. 2002). As these rings approach Barbados they are generally elliptical in shape and the associated circulation can exceed $450 \mathrm{~km}$ in diameter (Fratantoni \& Glickson 2002).

Cowen et al. (2003) provided a description of the impact of NBC rings on circulation around Barbados and the retention of locally produced fish larvae. Briefly, during repeated surveys around Barbados in May of 1990, 1996 and 1997, a vertical array of conductivity-temperature recorders and shipboard surveys revealed the presence of low-salinity pools of water indicative of NBC rings. Results from ichthyoplankton sampling during these time periods indicated that the 1990 and 1997 rings coincided with the flushing of locally produced reef-fish larvae away from the western end of the island, whereas the 1996 ring coincided with increased retention of locally produced larvae. The different impacts of these rings on local circulation were attributed to their geometry and trajectory as they passed Barbados (Cowen et al. 2003).

Sampling design. Ichthyoplankton sampling, using 3 different net types and targeting a range of depths, was carried out around Barbados between April and June of 1990, 1991, 1996 and 1997 (Table 1). In all years a $1 \mathrm{~m}^{2} 505 \mu \mathrm{m}$ mesh, multiple opening-closing 

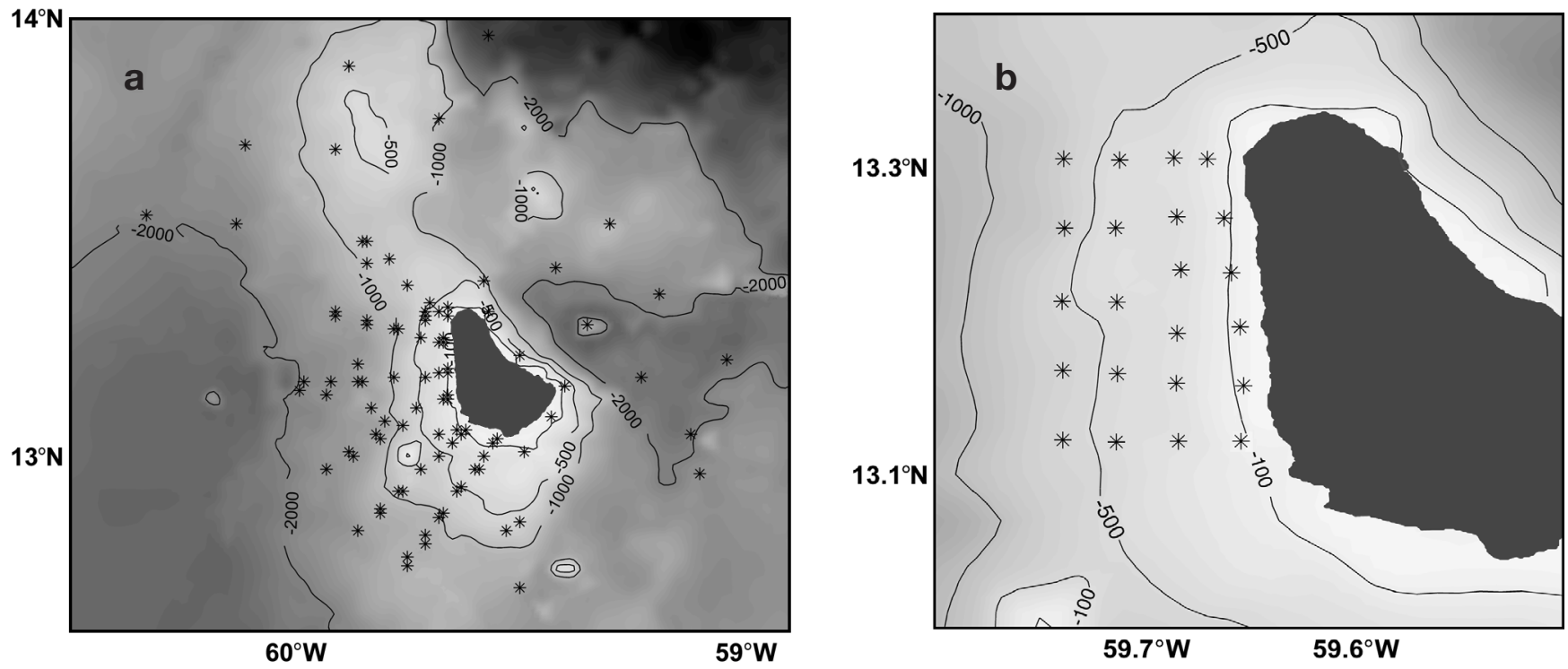

Fig. 2. Locations (*) of MOCNESS stations during (a) 1990 and 1991 cruises and (b) 1996 and 1997 cruises, showing depth contours (m)

net and environmental sensing system (MOCNESS) was used. This system allows the precise opening and closing of nets at targeted depths while continuously recording depth, volume of water filtered, temperature and salinity. Depth strata targeted in 1990 and 1991 were $0-10,10-30,30-60,60-90$ and 90-140 m. During 1996 and 1997 depths of $0-20,20-40,40-60$, 60-80 and 80-100 $\mathrm{m}$ were targeted. At most stations during all cruises, a $1 \times 2 \mathrm{~m}$ ( $1 \mathrm{~mm}$ mesh) frame net was towed at the surface for $10 \mathrm{~min}$, the volume of water filtered being estimated from the distance covered. Finally, in 1997, an additional MOCNESS with a $10 \mathrm{~m}^{2}$ opening and $3 \mathrm{~mm}$ mesh was used. The mesh size of this net was too wide to catch smaller leptocephali, but permitted the rapid sampling of large volumes of water. Samples were collected with the $10 \mathrm{~m}^{2}$ MOCNESS from as deep as $800 \mathrm{~m}$. Sampling of the physical environment using both shipboard surveys and moored samplers coincided with the biological sampling in all years. Details of the physical component of the sampling have been given by Bowman et al. (1994) and Paris et al. (2002).

The 1990 and 1991 cruises were broken into 3 legs and 2 legs respectively. Sampling during the first legs of both years and the third leg of 1990 occurred off the west coast of Barbados (Fig. 2a). Sampling during the second legs of both years occurred on all sides of the island up to $90 \mathrm{~km}$ from shore. For the 1996 and 1997 cruises, shipboard surveys were restricted to a smaller $15 \times 20 \mathrm{~km}$ area off the western coast of Barbados (Fig. 2b), an area previously shown to have higher larval fish densities. During these 2 cruises, a grid of 24 stations was sampled 8 times with the $1 \mathrm{~m}^{2}$ MOCNESS tows. Each sampling of the grid occurred during a single $24 \mathrm{~h}$ period with 3 to $5 \mathrm{~d}$ separating sampling periods. Intervening days were used to take physical measurements and, in 1997, to tow the $10 \mathrm{~m}^{2}$ MOCNESS. In all years, plankton tows were performed during both day and night. The overall sampling effort during the course of these 4 cruises was intense, with about 1000 net deployments sampling $>2$ million $\mathrm{m}^{3}$ of water (Table 1).

Samples in 1990, 1991, and 1996 were split; half the sample was preserved in $4 \%$ formalin, half was preserved in $95 \%$ ethanol. In 1997 the entire sample was preserved in ethanol with the exception of selected 10 $\mathrm{m}^{2}$ MOCNESS samples. Leptocephali were removed from the 1990, 1991, and 1996 formalin-preserved samples and the entire set of 1997 samples. These were identified following Böhlke (1989b) and their standard lengths were measured to the nearest $0.1 \mathrm{~mm}$ using digital calipers. No measurement corrections were made to account for shrinkage. We identified 6 leptocephalus types not described in Böhlke (1989b) to the lowest possible taxa and assigned a type in those cases where positive identification to species could not be made. These descriptions appear in Richardson \& Cowen (in press). A total of 116 small leptocephali (all $<10 \mathrm{~mm}$ ) and 11 damaged leptocephali could not be confidently identified to species or type. Some small individuals of Ariosoma coquettei and A. anale could not be differentiated. Distributional information on elopomorphs used in this study was primarily obtained from Böhlke $(1989 a, b)$, with additional information obtained from Smith (2002) and Fishbase (Froese \& Pauly 2000). Comparative distribution information on 
perciform taxa was primarily obtained from Fishbase (Froese \& Pauly 2000) and from Robins \& Ray (1986) and Allen (1991).

\section{RESULTS}

\section{Species composition and known geographic ranges}

A total of 4511 leptocephali, representing at least 68 species, 12 families and all 4 elopomorph orders were collected during the 4 sampling years (Table 2). Of the 68 identified leptocephali, 51 could be paired with described adults; 7 leptocephalus types (Ariosoma sp. A; Congridae, Genus B, sp. A; Ethadophis sp.; Gorgasia inferomaculata; Myrophinae sp. A; Hoplunnis sp. D; Ophichthini sp. 9) are larval species, i.e. the meristics of these leptocephali do not match the meristics of any described species in their taxonomic group, suggesting that the adult has not yet been described. Of the remaining 10 leptocephalus types, some may comprise more than 1 species (Paraconger spp., Gnathophis spp. and the Tilurus type of notacanthoid larvae); some most probably represent a single species, although a definitive species-level match cannot be made (Gymnothorax spp, A, B, C and F); and some are types that may or may not represent known species (Ophichthini sp. 1, Ophichthini sp. 8 and Bathycongrus sp.).

Over all 4 cruises, the mean catch rate of leptocephali was 246.9 individuals $\times 10^{5} \mathrm{~m}^{-3}$, excluding neuston samples and samples collected at depths of $>150 \mathrm{~m}$. A small number of species dominated the catches. Fewer than 10 individuals $\left(0.57\right.$ ind. per $\left.10^{5} \mathrm{~m}^{3}\right)$ were collected for 39 of the leptocephalus types, and only a single individual was collected for 17 of these. Gymnothorax ocellatus, a muraenid found in seagrass habitats throughout the Lesser Antilles and Guyanas accounted for $53 \%$ of the leptocephali collected, and Myrophis plumbeus, an ophichthid found in mangrove areas and brackish waters in the Guyanas and the eastern Atlantic, accounted for $12 \%$. The third most abundant species was Gorgasia inferomaculata, a garden-eel species that has never been collected as an adult, and has previously been collected as a leptocephalus only in the eastern Atlantic and south of the equator in the western Atlantic. The positive identification of this leptocephalus type as a species of Gorgasia was based on comparison with Indo-Pacific leptocephali (Castle 1997). Ariosoma coquettei, A. balearicum, Neoconger mucronatus, Paraconger spp. and $A$. anale were the next most abundant taxa. These taxa are all known to inhabit soft-bottom habitats in the Guyanas and are not known to occur in the Lesser Antilles (Smith $1989 a, b)$. A. balearicum is a species notable for regionally differing ranges in myomere counts (Smith 1989a), with indications that some populations migrate offshore to spawn and others spawn along the continental shelf (Miller 2002). The myomere counts for A. balearicum in the current sampling (mean $=129.8$, range $=$ 125 to 133) corresponded closely with the previously identified high-count population from the Guyanas and Brazil $($ mean $=129.2$, range 123 to 134, Smith 1989a).

Table 1. Distribution of sampling effort and total number of leptocephali collected during the cruises. Samples collected in 1990, 1991 and 1996 were split; half were preserved in formalin, half in ethanol; only formalin-preserved halves of those samples were used in this study. Frame net tows averaged $10 \mathrm{~min}$

\begin{tabular}{|c|c|c|c|c|c|c|c|}
\hline \multirow[t]{2}{*}{ Dates } & \multirow[t]{2}{*}{ Net } & \multirow{2}{*}{$\begin{array}{l}\text { Depth } \\
\text { range }(\mathrm{m})\end{array}$} & \multicolumn{3}{|c|}{ Stations } & \multirow{2}{*}{$\begin{array}{l}\text { Vol. filtered } \\
\qquad\left(\mathrm{m}^{3}\right)\end{array}$} & \multirow{2}{*}{$\begin{array}{c}\text { Total } \\
\text { leptocephali }\end{array}$} \\
\hline & & & Night & Day & Twilight & & \\
\hline 25 Apr 1990-19 May 1990 & $1 \mathrm{~m}^{2}$ MOCNESS & $0-140$ & 43 & 55 & 8 & $170796^{\mathrm{a}}$ & 88 \\
\hline 25 Apr 1990-19 May 1990 & $1 \times 2 \mathrm{~m}$ frame net & Surface & 34 & 38 & 4 & - & 15 \\
\hline 18 Apr 1991-2 May 1991 & $1 \mathrm{~m}^{2}$ MOCNESS & $0-140$ & 35 & 31 & 6 & $101777^{a}$ & 160 \\
\hline 3 May 1991 & $1 \times 2 \mathrm{~m}$ frame net & Surface & 9 & 3 & 1 & - & 4 \\
\hline 9 May 1996-4 Jun 1996 & $1 \mathrm{~m}^{2}$ MOCNESS & $0-100$ & 64 & 103 & 15 & $202144^{\mathrm{a}}$ & 554 \\
\hline 9 May 1996-4 Jun 1996 & $1 \times 2 \mathrm{~m}$ frame net & Surface & 58 & 94 & 6 & - & 26 \\
\hline 1 May $1997-27$ May 1997 & $1 \mathrm{~m}^{2}$ MOCNESS & $0-100$ & 75 & 80 & 9 & 222090 & 837 \\
\hline 1 May 1997-27 May 1997 & $1 \times 2 \mathrm{~m}$ frame net & Surface & 72 & 79 & 7 & - & 36 \\
\hline 3 May 1997-28 May 1997 & $10 \mathrm{~m}^{2}$ MOCNESS & $0-80$ & 17 & 1 & 1 & 534260 & 938 \\
\hline 3 May 1997-28 May 1997 & $10 \mathrm{~m}^{2}$ MOCNESS & $0-100$ & 22 & 2 & - & 712623 & 1769 \\
\hline 6 May 1997 & $10 \mathrm{~m}^{2}$ MOCNESS & $0-160$ & - & 2 & - & 61566 & 37 \\
\hline 6 May 1997 & $10 \mathrm{~m}^{2}$ MOCNESS & $0-200$ & - & 1 & - & 29697 & 0 \\
\hline 24 May 1997 & $10 \mathrm{~m}^{2}$ MOCNESS & $0-500$ & - & 1 & - & 49963 & 0 \\
\hline 11 May 1997-27 May 1997 & $10 \mathrm{~m}^{2}$ MOCNESS & $0-800$ & 1 & 2 & - & 211336 & 47 \\
\hline \multicolumn{3}{|l|}{ Total } & 430 & 492 & 57 & 2195180 & 4511 \\
\hline
\end{tabular}




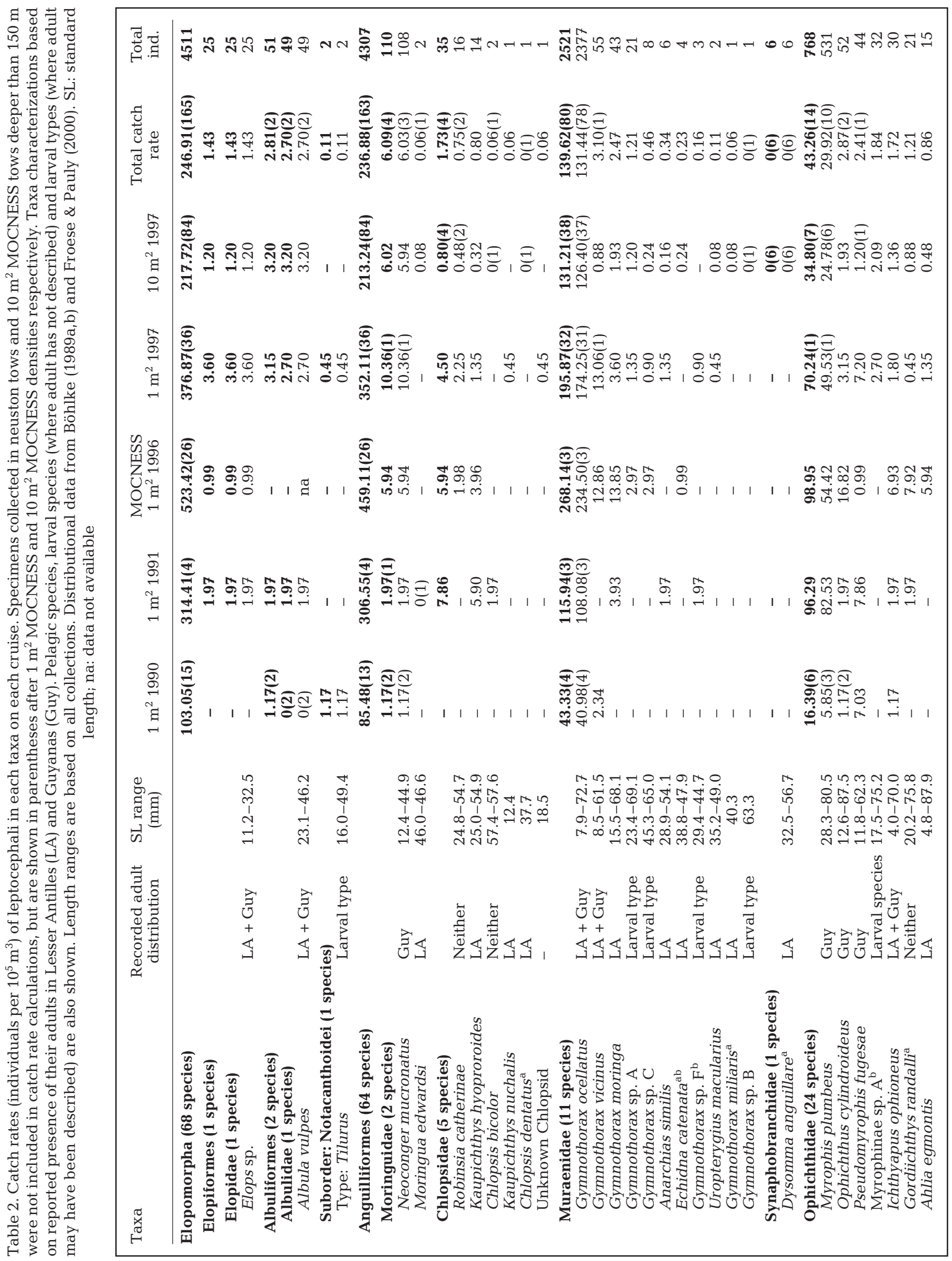




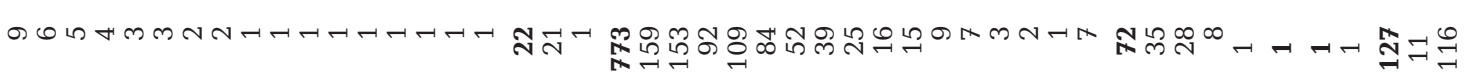

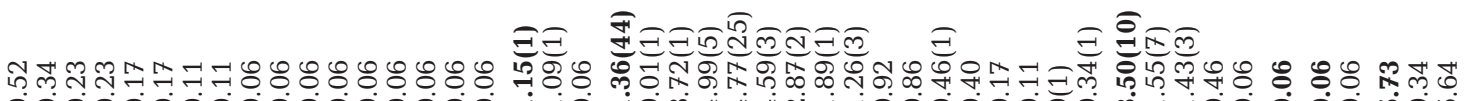
00000000000000000 i

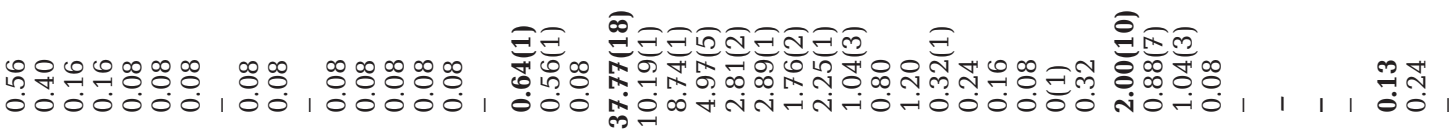

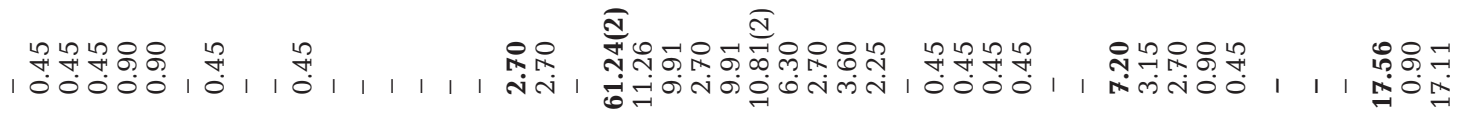

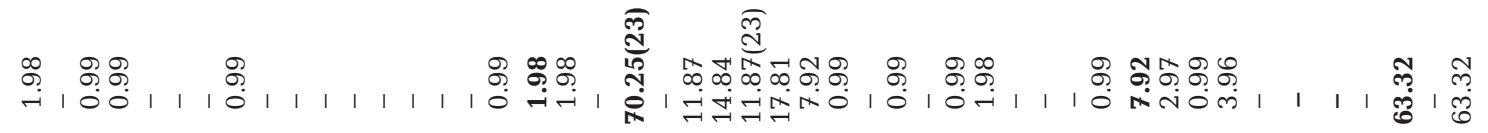

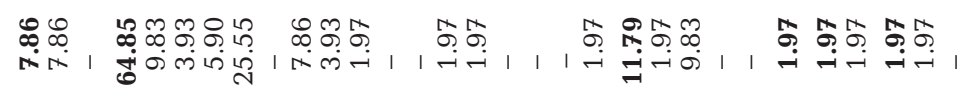

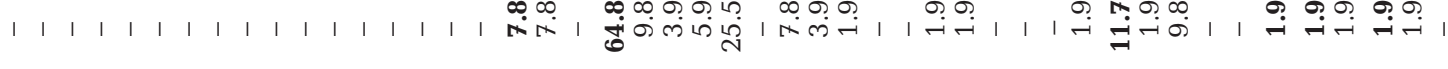

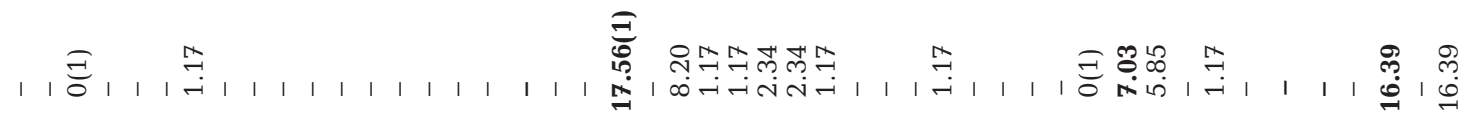

m.:-

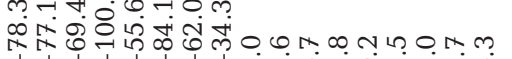

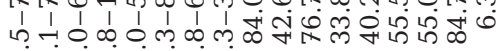
भiष

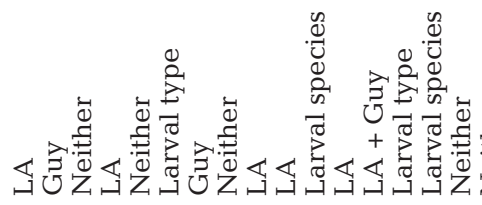

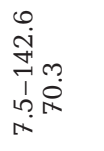

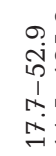

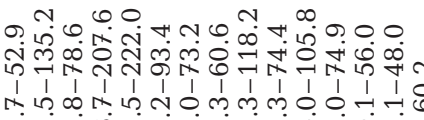

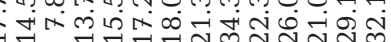

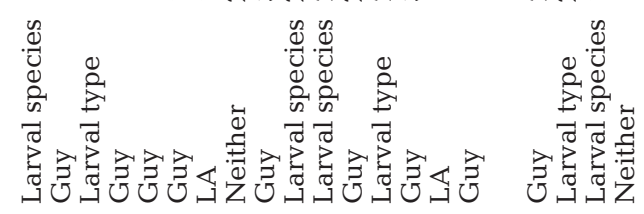

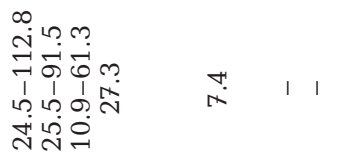

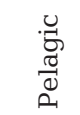

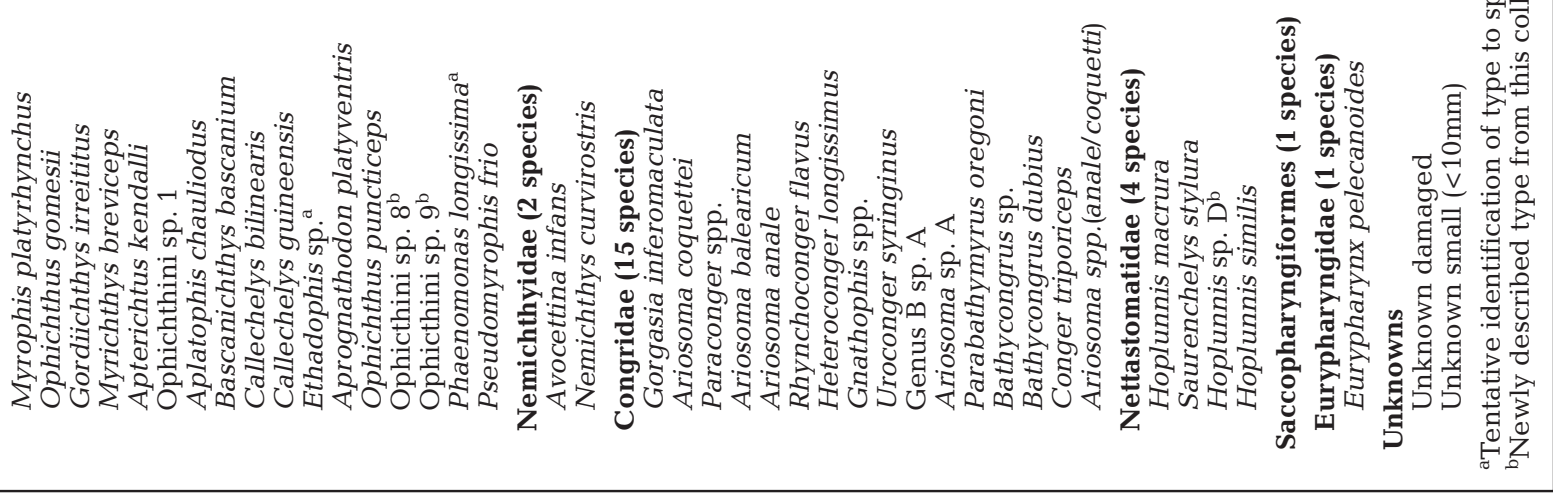




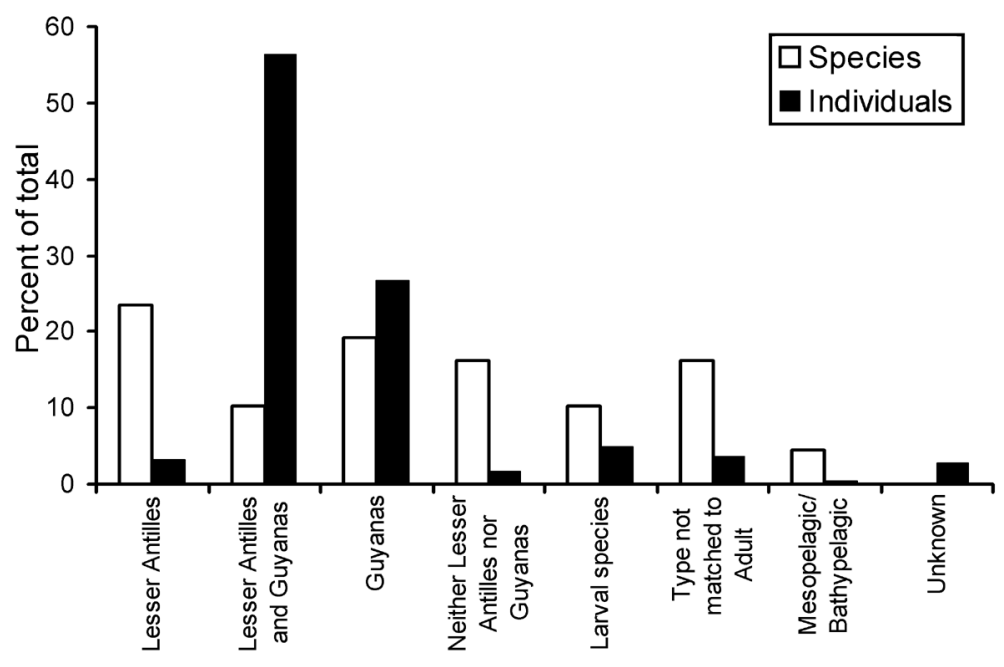

Fig. 3. Percentage of total number of species and individuals collected from around Barbados, showing distribution patterns reportetd for adults. Only Lesser Antilles and Guyanas biogeographic regions are considered herein. Leptocephalus types with meristics that do not match any species in the lowest taxonomic category to which they can be identified are grouped in 'Larval species' category. Leptocephalus types that may represent a known species are grouped in 'Type not matched to adult' category. Percentages based upon 68 species and 4511 individuals

Grouping the species and individuals based on the biogeographic regions in which their adults have been collected revealed large differences between the number of individuals and the number of species assigned to each group (Fig. 3). While Lesser Antillean species with no reported adult collections in the Guyanas comprised $23 \%$ of the species richness, they represented only $3.5 \%$ of the total catch of individuals. In contrast, Guyanan species with no reported adult collections in the Lesser Antilles comprised $20 \%$ of the species richness and $26 \%$ of the individuals collected. Species that have been collected in both biogeographic areas comprised only $10 \%$ of the species richness, but over $50 \%$ of the individuals collected, primarily due to the inclusion of Gymnothorax ocellatus in this group. A small portion of the collection comprised 3 additional species that inhabit mesopelagic or bathypelagic environments as adults (Avocettina infans, Nemichthys curvirostris and Eurypharynx pelecanoides). The remaining catch was composed of species that have not been collected in the Lesser Antilles or the Guyanas, larval species, and leptocephalus types that do not match to any single species.

Although constituting only a small fraction of the total collection, the number of individuals of the larval species and many of the leptocephalus types collected was noteworthy relative to the total known specimens of these types in scientific collections (Table 3). Myrophinae sp. A, Hoplunnis sp. D and Ophichthini sp. 9 are newly described leptocephalus types from this collection, and represent the larvae of undescribed species (Richardson \& Cowen in press). For the other 4 larval species (Ariosoma sp. A; Ethadophis sp.; Congridae, Genus B, sp. $A_{i}$ Gorgasia inferomaculata), the numbers of individuals collected in this study either equaled or exceeded the numbers previously reported in scientific collections from the western North Atlantic. The other reported specimen of Ethadophis sp. also came from Barbados (Leiby 1989), and the 4 reported specimens of Congridae, Genus B, sp. A were collected in the Virgin Islands (Smith 1989d). None of the previously reported specimens of the other 2 larval species have been collected in the Lesser Antilles (Table 3). This is also the first collection outside of the Gulf of Mexico of Ophichthini sp. 1, a leptocephalus type that may be the larvae of a known species. Additionally it is the first collection of Ophichthini sp. 8, another type that may match a described adult (Richardson \& Cowen in press).

Many of the species that have not been collected as adults in either the Guyanas or the Lesser Antilles are rare in scientific collections as both adults and leptocephali (Table 3). Phaenomonas longissima, Pseudomyrophis frio, and Gordiichthys randalli are all represented in both larval and adult collections by very few individuals. Although only a single adult specimen of Robinsia catherinae has been recorded in the western North Atlantic, the species is frequently collected as leptocephali across a wide geographic range. On the other hand, Bascanichthys bascanium, Hoplunnis similis, Apterichtus kendalli and Chlopsis bicolor are frequently collected along portions of their range as both adults and larvae.

\section{Temporal length distributions}

Individual species from this collection can be grouped together based on similar patterns of catch rate and length distributions over the 4 cruises (Fig. 4). Among many of the abundant species the most apparent changes in catch rate and length distributions occurred at the end of the 1990 and 1997 cruises. This time period coincided with the intrusion of low-salinity surface waters into the sample area (Fig. 4a), and conditions that favored the flushing away from the island of locally produced coral-reef fish larvae, such as the bluehead wrasse Thalassoma bifasciatum (Fig. 4b and Cowen et al. 2003).

For the Lesser Antillean species, such as Heteroconger longissimus (Fig. 4c) there was no consistent time 
Table 3. Previous reported distributions of leptocephali and adults of larval species and species that have not been recorded as adults for Guyanas or Lesser Antilles. Distributions and values primarily from Böhlke (1989a,b)

\begin{tabular}{|c|c|c|c|c|c|c|c|c|c|c|c|c|c|c|c|c|c|c|c|c|c|}
\hline & 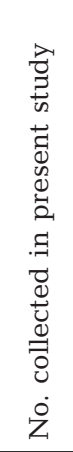 & 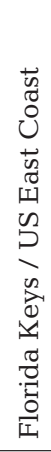 & 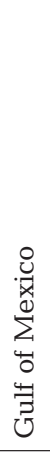 & 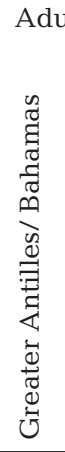 & 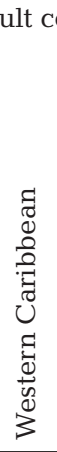 & 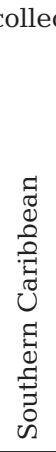 & 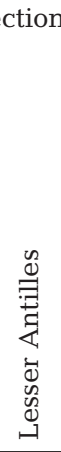 & 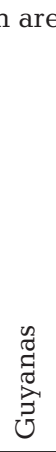 & 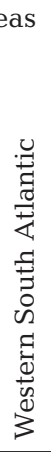 & 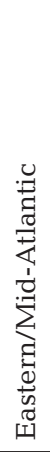 & 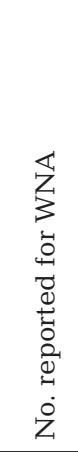 & 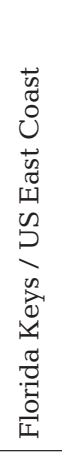 & 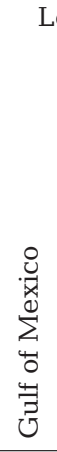 & 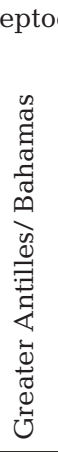 & 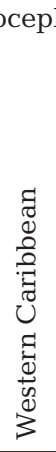 & 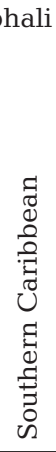 & 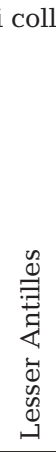 & 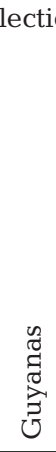 & 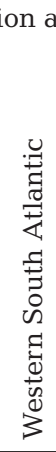 & 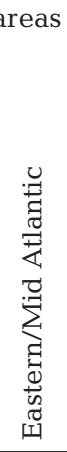 & 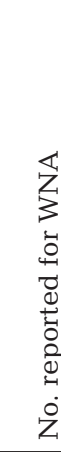 \\
\hline Gorgasia inferomaculata & 159 & & & & & & & & & & _- & & & & & & & & $\mathrm{x}$ & $\mathrm{x}$ & a \\
\hline Myrophinae sp. A & 32 & & & & & & & & & & - & & & & & & & & & & - \\
\hline Saurenchelys stylura & 26 & & & & & & & & & & - & & & & & & $\mathrm{x}$ & $\mathrm{x}$ & & $\mathrm{x}$ & $>20$ \\
\hline Gnathophis spp. & 25 & $\mathrm{x}$ & $\mathrm{x}$ & & $\mathrm{x}$ & & & & & & $>20$ & $\mathrm{x}$ & $\mathrm{x}$ & $\mathrm{x}$ & $\mathrm{x}$ & $\mathrm{x}$ & $\mathrm{x}$ & $\mathrm{x}$ & & $\mathrm{x}$ & $>20$ \\
\hline Gordichthys randalli & 21 & & & $\mathrm{x}$ & & & & & & & 8 & & $\mathrm{x}$ & & $\mathrm{x}$ & $\mathrm{x}$ & & $\mathrm{x}$ & & & 19 \\
\hline Robinsia catherinae & 16 & & & & & $\mathrm{x}$ & & & & & $1^{\mathrm{a}}$ & $\mathrm{x}$ & $\mathrm{x}$ & $\mathrm{x}$ & $\mathrm{x}$ & $\mathrm{x}$ & $\mathrm{x}$ & & & $\mathrm{x}$ & $>20$ \\
\hline Congridae Genus B sp. A & 15 & & & & & & & & & & - & & & & & & $\mathrm{x}$ & & & & 4 \\
\hline Ariosoma sp. A & 9 & & & & & & & & & & - & $\mathrm{x}$ & & $\mathrm{x}$ & $\mathrm{x}$ & & & & & & 5 \\
\hline Hoplunnis sp. D & 8 & & & & & & & & & & - & & & & & & & & & & - \\
\hline Gordichthys irretitus & 5 & & $\mathrm{x}$ & $\mathrm{x}$ & & & & & & & 6 & $\mathrm{x}$ & $\mathrm{x}$ & & & & $\mathrm{x}$ & $\mathrm{x}$ & & & $>20$ \\
\hline Apterichtus kendalli & 3 & $\mathrm{x}$ & & $\mathrm{x}$ & & $\mathrm{x}$ & & & & $\mathrm{x}$ & $>20$ & $\mathrm{x}$ & $\mathrm{x}$ & & & & & & & & $>20$ \\
\hline Ophichthini sp. 1 & 3 & & & & & & & & & & - & & $\mathrm{x}$ & & & & & & & & 15 \\
\hline Bascanichthys bascanium & 2 & $\mathrm{x}$ & $\mathrm{x}$ & $\mathrm{x}$ & & & & & & & $>20$ & $\mathrm{x}$ & $\mathrm{x}$ & $\mathrm{x}$ & & & & $\mathrm{x}$ & & & $>20$ \\
\hline Chlopsis bicolor & 2 & $\mathrm{x}$ & & & $\mathrm{x}$ & & & & $\mathrm{x}$ & $\mathrm{x}$ & $>20$ & $\mathrm{x}$ & $\mathrm{x}$ & $\mathrm{x}$ & $\mathrm{x}$ & & & & & & $>20$ \\
\hline Ethadophis sp. & 1 & & & & & & & & & & - & & & & & & $\mathrm{x}$ & & & & 1 \\
\hline Hoplunnis similis & 1 & & & $\mathrm{x}$ & $\mathrm{x}$ & & & & & & $>20$ & & & & $\mathrm{x}$ & & $\mathrm{x}$ & & & & $>20$ \\
\hline Phaenomonas longissima & 1 & & & & & & & & $\mathrm{x}$ & $\mathrm{x}$ & 6 & & $\mathrm{x}$ & & $\mathrm{x}$ & & & $\mathrm{x}$ & & & 7 \\
\hline Pseudomyrophis frio & 1 & & & & & $\mathrm{x}$ & & & $\mathrm{x}$ & & $1^{\mathrm{a}}$ & & $\mathrm{x}$ & & $\mathrm{x}$ & $\mathrm{x}$ & & & & & 6 \\
\hline Ophichthini sp. 8 & 1 & & & & & & & & & & - & & & & & & & & & & - \\
\hline Ophichthini sp. 9 & 1 & & & & & & & & & & - & & & & & & & & & & - \\
\hline
\end{tabular}

period during which either the minimum size individual or the highest abundances were found. Individuals $<15 \mathrm{~mm}$ in length of some of the Lesser Antillean species (e.g. Ahlia egmontis and Kaupichthys nuchalis) as well as Ichthyapus ophioneus, a species found in both the Lesser Antilles and Guyanas, were collected at various time periods during the cruise. For 5 of the 6 most abundant Guyanan species, Ariosoma anale, A. balearicum, A. coquettei, Neoconger mucronatus and Rhynchoconger flavus, both the minimum-sized individuals and high abundances coincided with the end of the 1990 and 1997 cruises (Fig. 4d-h). Minimum lengths of these species during the ends of the 1990 and 1997 cruises, were 10 to $20 \mathrm{~mm}$, in comparison to minimum lengths of $>20 \mathrm{~mm}$ during other portions of the cruises. Towards the end of the 1990 and 1997 cruises, we collected minimum-length individuals (although not in high densities) of 4 other less-abundant Guyanan species, Pseudomyrophis fugesae, Ophichthus cylindroideus, Uroconger syringinus and Hoplunnis macrura. Catch rates of Myrophis plumbeus, the most abundant Guyanan species, appeared to vary less than that of most other species during the cruises, with no peaks at the end of the 1990 and 1997 cruises (Fig. 4i). Although over 500 individuals of $M$. plumbeus were collected, the smallest individual was $28.7 \mathrm{~mm}$ and less than 30 individuals $<40 \mathrm{~mm}$ in length were collected. While small size classes and high abundances of Gymnothorax ocellatus, a species found in both the Guyanas and Lesser Antilles, were recorded during the end of the 1997 cruises, similar catch rates and smaller size classes were recorded at other times (Fig. 4j).

Many of the larval species and species not recorded from either the Lesser Antilles or the Guyanas had temporal patterns of abundances and length distributions similar to those of species of known origin, although few individuals were collected for many of these species. Specimens of Gorgasia inferomaculata $<25 \mathrm{~mm}$ in length were only collected during the last portion of the 1997 cruise, a period when catch rates increased though did not reach a peak (Fig. 4k). Gnathophis spp. and Saurenchelys stylura had higher catch rates and included minimum-length classes at the end of the 1997 cruise (Fig. 4l,m). Higher catch 
Standard length (mm)
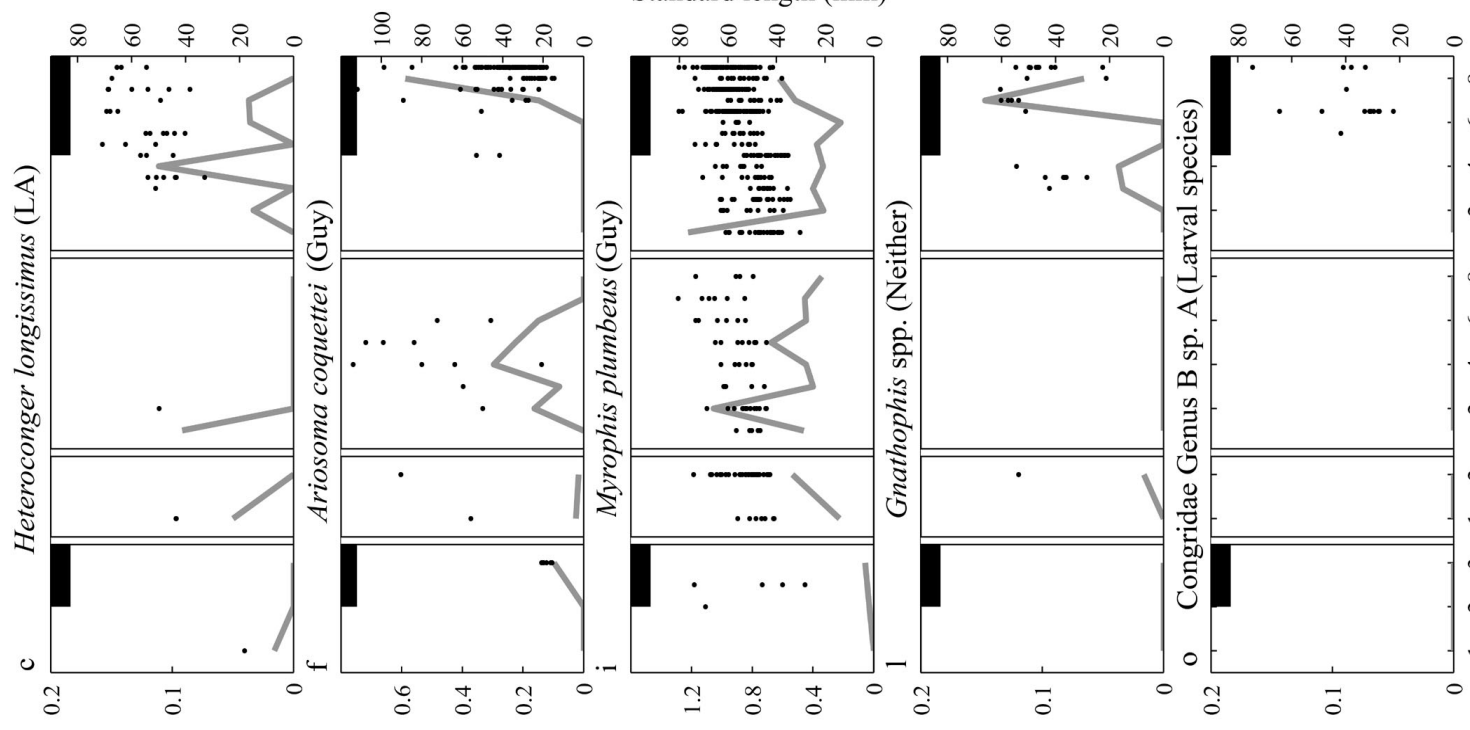

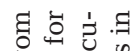

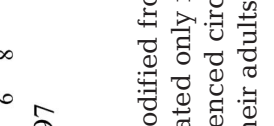

ลิ

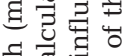

.

武

व

ลำ

है के

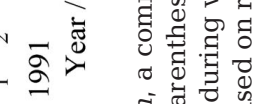

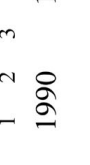

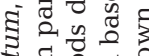

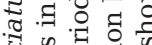

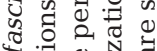

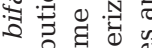
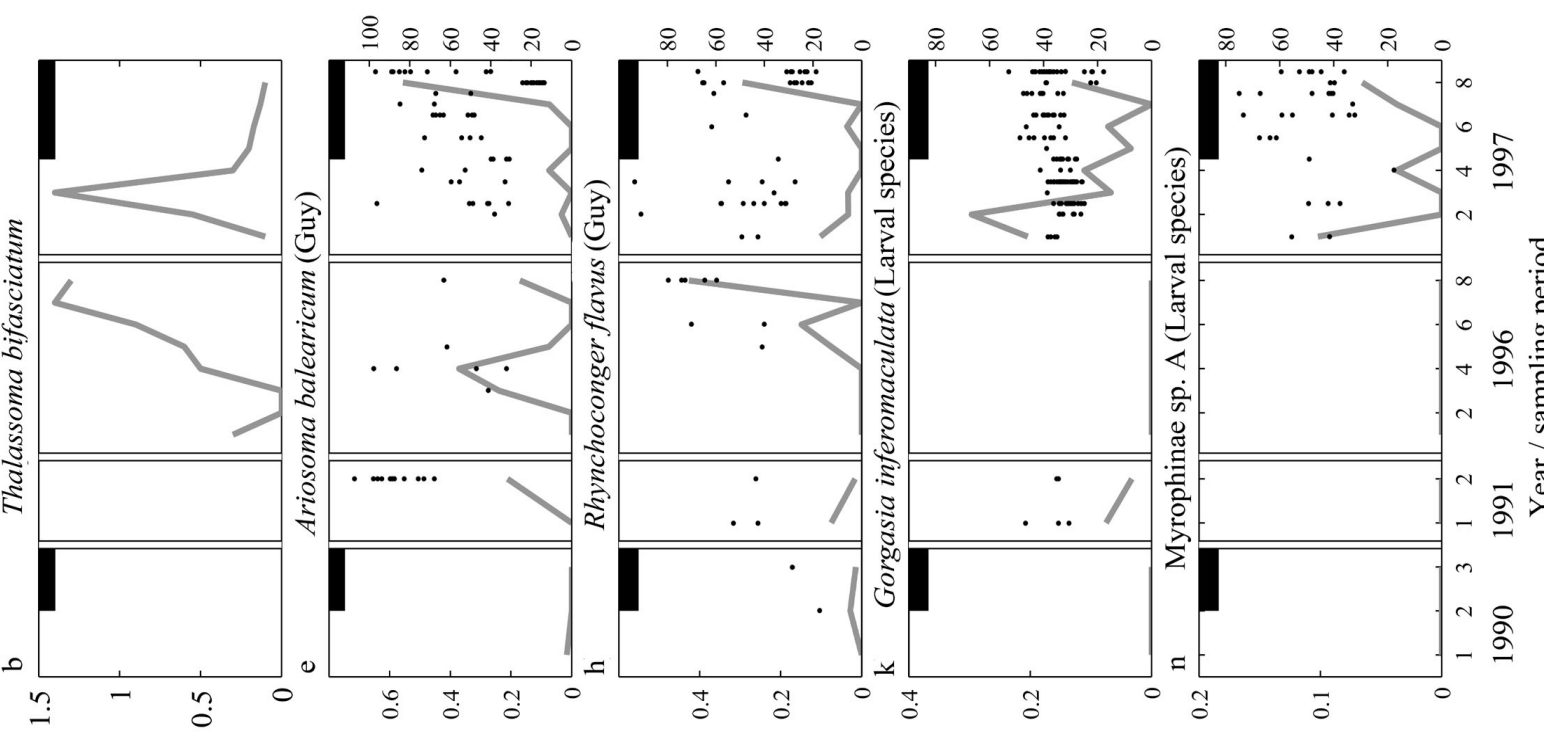



. 궁

원

สี

此

- 0 용

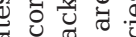

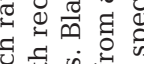

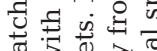

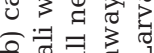

을 중

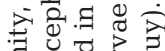

.

(2) 원 त्ञ

$4 \div 0$ 约

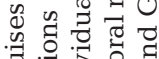

ป气 :

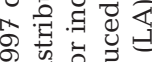

;)

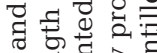
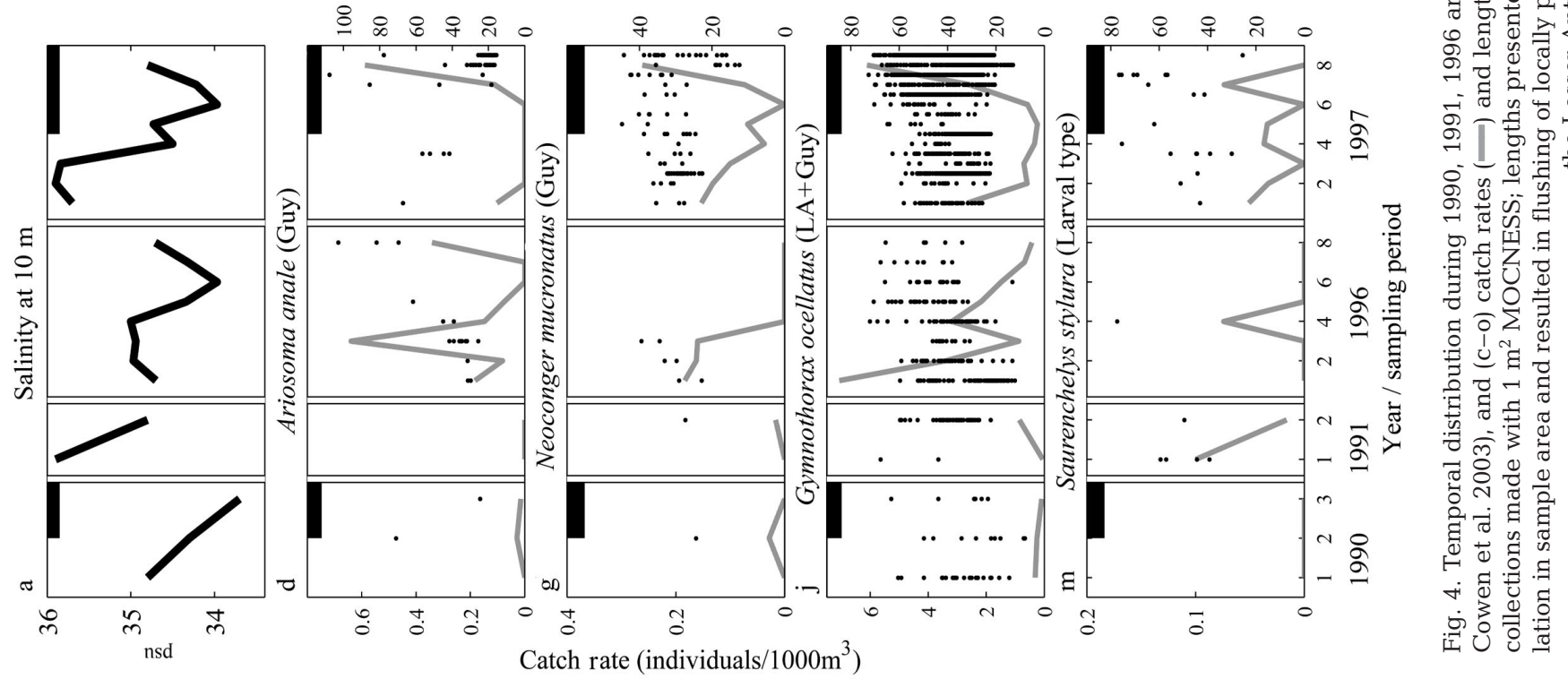
rates of Myrophinae sp. A, and the only individuals of Congridae, Genus B, sp. A found in the study were also collected near the end of the 1997 cruise (Fig. 4n,o). Also during this time period 7 out of a total of 9 specimens were collected and the shortest lengths of Ariosoma species A was recorded. In comparison, very small ( $<15 \mathrm{~mm}$ ) individuals of Hoplunnis sp. D, Gordiichthys irreititus, Pseudomyrophis frio and Bascanichthys bascanium were collected during all time periods except the latter half of both the 1990 and 1997 cruises.

\section{DISCUSSION}

The direction of flow in the region around Barbados assures that leptocephali collected near Barbados were either produced locally or were spawned upcurrent, in the Guyanas, and then transported into the area. However, nearly a quarter of the species collected have not been recorded as adults in either the Lesser Antilles or the Guyanas, indicating the existence of populations that have avoided detection in one or both of these biogeographic areas. The determination of which biogeographic region is most likely to be the source of each of these leptocephalus types is facilitated by previous characterizations of the temporal distribution of oceanographic processes around Barbados (Bowman et al. 1994, Cowen \& Castro 1994, Paris et al. 2002, Cowen et al. 2003), and the impact of the 2 main large-scale transport mechanisms in the region, the Guyana current and NBC rings, on the densities and size distributions of leptocephali from different regions.

Variations in the densities of leptocephali expatriated from the Guyanas are in part attributable to processes that affect their transport into the sample area. In contrast to the Guyana current, NBC rings contain a strong component of flow perpendicular to the South American continental shelf and towards Barbados. Larvae spawned along the South American coast could be entrained in this flow and moved offshore. A high level of transport of Guyanan larvae by an NBC ring into the nearshore waters of Barbados would depend on the geometry and trajectory of a ring as it passes both South America and Barbados. The NBC rings considered in this study were only sampled around Barbados, and thus there are no indications of their geometry or trajectory as they passed the Guyanas area of South America. Circulation patterns in the sample area around Barbados indicate a more westward passage of the NBC rings past Barbados in 1990 and 1997 than in 1996. The result was the flushing of locally produced larvae away from the western shore of the island during the 1990 and 1997 samplings, in comparison to the retention of locally produced larvae during the 1996 sam- pling (Cowen et al. 2003). The temporal distribution of leptocephali of known origin shows that coincident with the flushing of locally produced larvae was the import of Guyanan larvae, such as Ariosoma anale, A. balearicum, A. coquettei, Neoconger mucronatus and Rhynchoconger flavus, resulting in a peak in abundance of these species. During the time period when the presence of a NBC ring coincided with the retention of locally produced larvae, no observable increase in the abundance of Guyanan larvae occurred.

The temporal distribution of small size classes of Guyanan species indicate that NBC rings not only influenced the densities of expatriated leptocephali but also the transport times of these larvae from the Guyanas to Barbados. Although only about $25 \%$ of the sampling occurred during the 1990 or 1997 NBC ring events, the minimum sizes of 9 of the 10 most abundant Guyanan species were collected during these periods. Reported age-length relationships for one Guyanan species, Ariosoma balearicum, allowed the estimation of age differences between larvae collected when a ring was present around Barbados and larvae collected when a ring was absent. Based on growth rates of $1 \mathrm{~mm} \mathrm{~d}^{-1}$ obtained in the Gulf of Mexico by Bishop et al. (2000), there would be an estimated $17 \mathrm{~d}$ age difference between the smallest $(13.7 \mathrm{~mm})$ A. balearicum leptocephali collected around Barbados during a ring event versus the smallest $(30.9 \mathrm{~mm})$ individual collected when a ring was not present. There are 2 factors that could contribute to this difference in estimated age: (1) current speeds along the edge of NBC rings (which may exceed $100 \mathrm{~cm} \mathrm{~s}^{-1}$ ) are much faster than those in the Guyana Current (Frantantoni \& Glickson 2002); (2) along the leading edge of an NBC ring, flow moves perpendicular to and away from the South American continental shelf, greatly increasing the likelihood at a closer source location to Barbados of Guyaran leptocephali transported by an NBC ring versus the Guyana Current.

Interestingly, the one abundant Guyanan species with leptocephali densities and length-frequency distributions that varied least in response to NBC rings, $M Y$ rophis plumbeus, may migrate offshore to spawn. $M$. plumbeus is a member of a subfamily for which an offshore spawning migration of approximately $160 \mathrm{~km}$ has been observed in a related species, Ahlia egmontis (Cohen \& Dean 1970). Additionally, M. plumbeus occupies brackish to freshwater areas, which are not favorable to leptocephali development (Smith 1989c), and thus are unlikely to spawn in their adult habitat. If M. plumbeus were to spawn far enough offshore, a component of transport perpendicular to the continental shelf would not be required for their larvae to reach Barbados, allowing their transport to Barbados by the consistently present Guyana Current rather than periodic NBC 
rings. This may explain why amongst all the expatriate species the densities of this species varied the least in response to NBC rings, and also why no very small leptocephali of this species, indicative of the rapid transport of NBC rings, were found during the sampling.

Based on temporal patterns of density and length distributions similar to those of leptocephali of known origin, it is possible to assign likely source locations for 10 leptocephali of species that have not been collected as adults in either the Lesser Antilles or the Guyanas. Increases in density, during the 1997 current ring, of Gorgasia inferomaculata; Myrophinae sp. $\mathrm{A}_{\text {; }}$ Congridae, Genus B, sp. A; and Gnathophis spp. suggests a Guyanan origin for these species. Additionally, the collection of minimum-sized individuals of Gorgasia inferomaculata, Saurenchelys stylura and Ariosoma sp. A during either the 1990 or 1997 ring events suggests that these 3 species are also present as adults in the Guyanas. In contrast, the fact that very small individuals $(<15 \mathrm{~mm})$ of Hoplunnis sp. D, Gordiichthys irreititus, Pseudomyrophis frio and Bascanichthys bascanium were collected during time periods other than when these rings were present suggests that adults of these species probably occur around Barbados. Despite the intensity of sampling during this study, too few individuals were collected of 7 additional species (Gordiichthys randalli, Robinsia catherinae, Ethadophis sp., Phaenomonas longissima, Chlopsis bicolor, $H$. similis and Apterichtus kendalli) to speculate about the biogeographic area in which the adults of these species are likely to occur.

Uncertainty in the understanding of diversity and geographic distribution of elopomorph species excludes them from most studies that synthesize largescale ecological patterns. This allows a taxonomically narrow range of families, such as Pomacentridae, Labridae, Pomacanthidae and Chaetodontidae to dictate general conclusions about the patterns and processes contributing to tropical marine fish distributions. The exclusion of elopomorph families from analyses that require an island-scale resolution of species distributions (i.e. Jones et al. 2002) is well justified. On the other hand, by considering only the presence or absence of a species across major biogeographic barriers it is possible to make rough comparisons of elopomorph families to more commonly studied perciform families. For example, in the Pacific Ocean, the Hawaiian Islands are isolated from the other shallow-water areas, leading to high levels of endemism. Böhlke \& Randall (2000) noted that muraenids have lower levels of endemism in the Hawaiian Island than common perciform families, while McCosker (2002) noted that levels of endemism in the family Ophichthidae were similar to levels for more commonly studied families. In the Atlantic, major biogeographic boundaries for shallow-water benthic species exist between the western North Atlantic and the eastern Atlantic and midAtlantic islands (Briggs 1974). A comparison between families of the percentage of western North Atlantic species with distributions that cross these major biogeographic boundaries reveals that muraenid species tend to be much more broadly distributed than pomacentrid, labrid, congrid and ophichthid species (Table 4).

These differences in levels of endemism in Hawaiian fishes and the frequency of cross-Atlantic distributions both between elopomorphs and perciforms and within elopomorphs may arise from differences in their life histories. The maximum pelagic larval duration (PLD) of a species imposes a limit to dispersal that may impact range expansion in a species. However most studies that have attempted to correlate maximum larval duration and range size have found a minimal relationship between the two (Victor 1986, Thresher et al. 1989, Wellington \& Victor 1989, Jones et al. 2002). The rare work that has been done on aging anguilliform species, other than anguillids, indicates that the duration to metamorphosis for most species ranges from 60 to 120 d (Brothers \& Thresher 1985, Bishop et al. 2000). These durations exceed those of most perciform species, although they overlap the ranges of a few labrids (Victor 1986). It cannot be ruled out that differences in PLD are partially responsible for differences between muraenid species and perciform species in the frequency of crossAtlantic distributions or levels of Hawaiian endemism. Feeding requirements and growth strategies are additional factors that differ considerably between leptocephali and perciform larvae and may determine the ability of a larva to be successfully transported long distances. Leptocephali are most probably not obligate plankton feeders (Pfeiler 1986, Bishop \& Torres 2001) and store extensive energy reserves for use at metamorphosis (Pfeiler 1986, Bishop et al. 2000). These 2 factors may allow them to endure suboptimal

Table 4. Number $(\mathrm{N})$ of species of 3 elopomorph families (Muraenidae, Ophichthidae, Congridae) and 2 perciform families (Pomacentridae and Labridae) recorded in western North Atlantic (WNA) and percentages in 2 other broad geographic areas of the Atlantic, middle Atlantic Islands and eastern Atlantic

\begin{tabular}{|lccr|}
\hline \multirow{2}{*}{ Family } & N in & \multicolumn{2}{c|}{$\%$ in } \\
\cline { 3 - 4 } & WNA & Mid-Atl. & E. Atl. \\
\hline Muraenidae & 23 & $61 \%$ & $43 \%$ \\
Ophichthidae & 56 & $9 \%$ & $5 \%$ \\
Congridae & 37 & $5 \%$ & $13 \%$ \\
Labridae & 21 & $6 \%$ & $0 \%$ \\
Pomacentridae & 16 & $13 \%$ & $5 \%$ \\
\hline
\end{tabular}


conditions in their environment better than perciform larvae. Differences in growth rate and survivorship of reef-fish larvae between different oceanic habitats have been found (Sponaugle \& Pinkard 2004), although the distributions of poor growth habitats and their impact on the probability of successful long-distance dispersal have not been quantified. It is possible that the growth strategies and feeding requirements of larvae are more important in determining successful long-distance dispersal than larval duration.

The reason for differences in cross-Atlantic distributions or Hawaiian endemism between muraenids and perciform taxa but not ophichthids or congrids and perciform taxa is not readily explained. Little comparative work on the larval ecology or duration of species in these elopomorph families has been done. Aging studies of leptocephali of 1 muraenid species, 2 congrid species and 1 ophichthid species have not revealed differences in larval duration between these families that might account for these differences (Bishop \& Torres 2001). It is possible that these biogeographic differences are related to juvenile or adult life history traits that impact the ability of a species to settle and establish a population in an area, but this possibility cannot be addressed due to the scarcity of basic life history information on adult elopomorphs.

Life history differences between elopomorphs and more commonly studied taxa as well as the diversity of life history strategies within the subdivision Elopomorpha offer an opportunity for comparative studies of the physical processes and biological traits that affect the distribution and abundance of species. However, most often elopomorph species are overlooked in work on both the adult and larval stages. This study has shed light on the ability of 1 oceanographic feature, NBC rings, to transport larvae from the Guyanas to the Lesser Antilles, although the importance of this transport pathway at a population level is limited to those species that are able to find a suitable habitat in both the Guyanas and the Lesser Antilles. Additionally, this study expanded the known geographic ranges of some elopomorph species and has highlighted some broad distribution differences between elopomorph and perciform species. While it is likely that the unique leptocephalus larval stage of elopomorph fishes contributes to these differences, many other explanations for distributional differences between species (see Jones et al. 2002) could not be examined because of a scarcity of available life-history information on elopomorphs. Further work documenting the distribution of the rarer species combined with ecological studies on larval and adult elopomorphs would refine our understanding of how and why distribution and abundance patterns in this diverse group differ from or are similar to those of more commonly studied taxonomic groups.
Acknowledgements. Special thanks to C. Paris for her valuable advice on all aspects of this study and her assistance with the specimens and collection data. Discussions with $\mathrm{S}$. Sponaugle, M. Sullivan and S. Luthy improved this manuscript considerably. We also thank D. G. Smith for his comments on the identification of many of the uncommon leptocephali and for assisting in the donation of specimens to the USNM. This study was supported by grants from the National Science Foundation (OCE-8911120 \& OCE-9521104) to R. K. C. and a University of Miami Maytag Fellowship to D. E. R.

\section{LITERATURE CITED}

Allen GR (1991) Damselfishes of the world. Hans A. Baensch, Melle

Bishop RE, Torres JJ (2001) Leptocephalus energetics: assembly of the energetics equation. Mar Biol 138:1093-1098

Bishop RE, Torres JJ, Crabtree RE (2000) Chemical composition and growth indices in leptocephalus larvae. Mar Biol 137:205-214

Böhlke EB (ed) (1989a) Fishes of the western North Atlantic: Anguilliformes and Saccopharyngiformes. Mem Sears Found Mar Res 9(1)

Böhlke EB (ed) (1989b) Fishes of the western North Atlantic: Leptocephali. Mem Sears Found Mar Res 9(2)

Böhlke EB, Randall JE (2000) A review of the moray eels (Anguilliformes: Muraenidae) of the Hawaiian Islands, with descriptions of two new species. Proc Acad Nat Sci Phila 150:203-278

Bowman MJ, Stansfield KL, Fauria SJ, Wilson TC (1994) Coastal ocean circulation near Barbados, West Indies, spring 1990 and 1991. J Geophys Res C 99:16131-16142

Briggs JC (1974) Marine zoogeography. McGraw-Hill, New York

Brothers EB, Thresher RE (1985) Pelagic duration, dispersal, and the distribution of Indo-Pacific coral reef fishes. NOAA Symp Ser Undersea Res 2:53-69

Castle PHJ (1997) Garden eel leptocephali: characters, generic identification, distribution, and relationships. Bull Mar Sci 60:6-22

Cohen DM, Dean D (1970) Sexual maturity and migratory behaviour of the tropical eel, Ahlia egmontis. Nature 227: 189-190

Cowen RK, Castro LR (1994) Relation of coral reef fish larval distributions to island scale circulation around Barbados, West Indies. Bull Mar Sci 54:228-244

Cowen RK, Sponaugle S, Paris CB, Fortuna JL, Lwiza KMM, Dorsey S (2003) Impact of North Brazil Current rings on local circulation and coral reef fish recruitment to Barbados, West Indies. Elsevier Oceanogr Ser 68:443-462

Crabtree RE, Cyr EC, Bishop RE, Falkenstein LM, Dean JM (1992) Age and growth of tarpon, Megalopos atlanticus, with notes on relative abundance and probable spawning areas. Environ Biol Fish 35:361-370

Fratantoni DM, Glickson DA (2002) North Brazil Current ring generation and evolution observed with SeaWIFS. J Phys Oceanogr 32:1058-1074

Froese R, Pauly D (eds) (2000) Fishbase 2000: concepts, design and data sources. ICLARM, Los Banos, Laguna, Phillipines

Hare JA, Cowen RK (1991) Expatriation of Xyrichthys novacula (Pisces: Labridae) larvae: evidence of rapid crossslope exchange. J Mar Res 49:801-823

Jones GP, Caley MJ, Munday PL (2002) Rarity in coral reef fish communities. In: Sale PF (ed) Coral reef fishes: dynamics and diversity in a complex ecosystem. Academic Press, San Diego, CA, p 81-102 
Keller A (1976) Systematics, vertical distribution, and life history of anguilliform leptocephali in the Bermuda Ocean Acre. MS thesis, University of Rhode Island

Kelly PS, Lwiza KMM, Cowen RK, Goni GJ (2000) Low-salinity pools at Barbados, West Indies: their origin, frequency and variability. J Geophys Res C 105:19699-19708

Leiby MM (1989) Family Ophichthidae. Mem Sears Found Mar Res 9(2):764-897

Limouzy-Paris C, McGowan MF, Richards WJ, Umaran JP, Cha SS (1994) Diversity of fish larvae in the Florida Keys: results from SEFCAR. Bull Mar Sci 54:857-870

Macintyre IG (1968) Preliminary mapping of the insular shelf off the west coast of Barbados, West Indies. Caribb J Sci 8: 95-100

McCosker JE (2002) Notes on Hawaiian snake eels (Pisces: Ophichthidae), with comments on Ophichthus bonaparti. Pac Sci 56:23-34

Miller MJ (1995) Species assemblages of leptocephali in the Sargasso Sea and Florida Current. Mar Ecol Prog Ser 121: $11-26$

Miller MJ (2002) The distribution and ecology of Ariosoma balearicum (Congridae) leptocephali in the western North Atlantic. Environ Biol Fish 63:235-252

Miller MJ, McCleave JD (1994) Species assemblages of leptocephali in the Subtropical Convergance Zone of the Sargasso Sea. J Mar Res 52:743-772

Miller MJ, Otake $\mathrm{T}$, Minagawa $\mathrm{G}$, Inagaki $\mathrm{T}$, Tsukamoto $\mathrm{K}$ (2002) Distribution of leptocephali in the Kuroshio Current and East China Sea. Mar Ecol Prog Ser 235:279-288

Mochioka N, Iwamizu M (1996) Diet of anguilloid larvae: leptocephali feed selectively on larvacean houses and fecal pellets. Mar Biol 125:447-452

Paris CB, Cowen RK, Lwiza KMM, Wang D, Olson DB (2002) Multivariate objective analysis of the coastal circulation of Barbados, West Indies: implications for larval transport. Deep-Sea Res I 49:1363-1386

Paris CB, Cowen RK (2004) Direct evidence of a biophysical retention mechanism for coral reef fish larvae. Limnol Oceanogr 49:1964-1979

Pfeiler E (1986) Towards an explanation of the development strategy in leptocephalus larvae of marine fishes. Environ Biol Fish 15:3-13

Richardson DE, Cowen RK (in press) New leptocephali types collected around the Island of Barbados, West Indies. Copeia

Editorial responsibility: Howard Browman (Contributing Editor), Storebø, Norway
Robins CR, Ray GC (1986) A field guide to Atlantic coast fishes: North America. Houghton Mifflin Company, Boston, MA Schmidt J (1922) The breeding places of the eel. Philos Trans R Soc Lond 211:179-208

Smith DG (1989a) Family Congridae. In: Böhlke EB (ed) Fishes of the western North Atlantic: Anguilliformes and Saccopharyngiformes. Mem Sears Found Mar Res 9(1):460-567

Smith DG (1989b) Family Moringuidae. In: Böhlke EB (ed) Fishes of the western North Atlantic: Anguilliformes and Saccopharyngiformes. Mem Sears Found Mar Res 9(2):55-71

Smith DG (1989c) Introduction to Leptocephali. In: Böhlke EB (ed) Fishes of the western North Atlantic: Leptocephali. Mem Sears Found Mar Res 9(2):657-668

Smith DG (1989d) Family Congridae. In: Böhlke EB (ed) Fishes of the western North Atlantic: Leptocephali. Mem Sears Found Mar Res 9(2):723-763

Smith DG (2002) Larvae of the garden eel genus Gorgasia (Congridae, Heterocongrinae) from the Western Caribbean Sea. Bull Mar Sci 70:831-836

Sponaugle S, Pinkard D (2004) Impact of variable pelagic environments on natural larval growth and recruitment of a reef fish. J Fish Biol 64:34-54

Stansfield KL, Bowman MJ, Fauria SJ, Wilson TC (1995) Water mass and coastal current variability near Barbados, West Indies. J Geophys Res C 100:24819-24830

Thresher RE, Colin PL, Bell LJ (1989) Planktonic duration, distribution and population structure of Western and Central Pacific damselfishes (Pomacentridae). Copeia 1989:420-434

Victor BC (1986) Duration of the planktonic larval stage of one hundred species of Pacific and Atlantic wrasses (family Labridae). Mar Biol 90:317-326

Victor BC (1991) Settlement strategies and biogeography of reef fishes. In: Sale PF (ed) The ecology of fishes on coral reefs. Academic Press, San Diego, CA, p 231-252

Victor BC, Wellington GM (2000) Endemism and the pelagic larval duration of reef fishes in the eastern Pacific Ocean. Mar Ecol Prog Ser 205:241-248

Wellington GM, Victor BC (1989) Planktonic larval duration of one hundred species of Pacific and Atlantic damselfishes (Pomacentridae). Mar Biol 101:557-567

Wilson WD, Johns WE, Garzoli SL (2002) Velocity structure of North Brazil Current rings. Geophys Res Lett 29:1-3

Submitted: March 26, 2004; Accepted: June 21, 2004

Proofs received from author(s): November 5, 2004 